\title{
Archipel
}

ARCHIPEL Études interdisciplinaires sur le monde insulindien

99 | 2020

Varia

\section{Forty Years of Silence: The Insanity of Society}

Soe Tjen Marching

\section{(2) OpenEdition}

Journals

Electronic version

URL: http://journals.openedition.org/archipel/1657

DOI: 10.4000/archipel. 1657

ISSN: 2104-3655

\section{Publisher}

Association Archipel

\section{Printed version}

Date of publication: 15 July 2020

Number of pages: $35-40$

ISBN: 978-2-910513-83-2

ISSN: 0044-8613

\section{Electronic reference}

Soe Tjen Marching, "Forty Years of Silence: The Insanity of Society", Archipel [Online], 99 | 2020, Online since 02 June 2020, connection on 15 March 2021. URL: http://journals.openedition.org/archipel/ 1657 ; DOI: https://doi.org/10.4000/archipel. 1657 
SOE TJEN MARCHING ${ }^{1}$

\section{Forty Years of Silence: The Insanity of Society}

Forty Years of Silence: An Indonesian Tragedy

Documentary, 87 min., 2009

Director : Robert Lemelson

Producer : Elemental Production

Distributed via : http://40yearsofsilence.com/\#shop

Language : Indonesian and English, with English subtitles

Millions of people were murdered, imprisoned, tortured and/or raped in 1965-66 in Indonesia. Whereas this tragic episode of Indonesian history has been exposed by scholars for decades, it has been silenced by the majority of the population who has been taught, in the New Order, a one-side narration which left no place for the voice of the victims. With the exception of Gus Dur or Abdurrachman Wahid, every Indonesian President since and including Soeharto have denied that this ever happened. Soeharto stepped down, but he was never brought to justice before his death in 2008; and his cronies, such as Titiek Soeharto and Prabowo Subianto, are still free to hold important political positions. When Jokowi was first elected in 2014, many victims of the 1965 genocide became more optimistic about the prospects for justice. Jokowi promised to deal with past human rights abuses in Indonesia. This promise nevertheless has never been realised. In 2017, he even seemed to support the New Order's discourse by attending the screening of the New

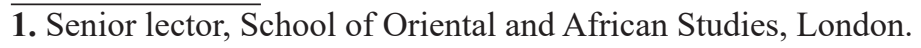


Order propaganda film Pengkhianatan G30S/PKI [The Treachery of the G30S/PKI] in Bogor, West Java, and by allowing this film to be screened on national TV. In October 2019, Jokowi became an honorary member of Pemuda Pancasila, the youth group that took part in the genocide of the communists and alleged communists in 1965-1966. Soon after Jokowi's second inauguration as President in 2019, he appointed Prabowo Subianto, an ex-army general accused of human rights violations, to be Minister of Defence. The new minister instructed school teachers to teach "the truth and nothing but the truth" about the history of the rebellion of the Indonesian Communist Party (PKI) and its brutality. ${ }^{2}$

It is for this reason that the film 40 Years of Silence remains relevant in today's Indonesia. The film concentrates on the psychological conditions of the characters, including trauma and PTSD (post-traumatic stress disorder), allowing to see the long-term impact of the violence on the people's mental health. The director, Robert Lemelson, is a psychological anthropologist as well as a documentary filmmaker. He has worked in Southeast Asia particularly in Indonesia and since early 2000, he has been writing about mental illnesses in Indonesia. Shot between 2002 and 2006, the film 40 Years of Silence focuses on the stories of four families that had been the subject of "ongoing clinical visual ethnographic research on culture and mental illness in Indonesia conducted by Robert Lemelson over a ten-year period". ${ }^{3}$ Lemelson interviewed these families and depicted their activities and surroundings including their homes, places of worship, schools and playgrounds.

In this film, Lemelson also involved researchers, psychiatrists and counselors both from Indonesia and USA, who gave comments on the historical and political backgrounds of the film and the behaviour of some of the characters. Lemelson juxtaposed the interviews of the characters with black and white documentary excerpts from the 1965-67 genocide, analyses from the experts, as well as short excerpts from the propaganda film Pengkhianatan G30S/PKI. This technique renders the visual images of how the intense terror surrounds the victims and their families for many years, more powerful. The contrasts between the New Order propaganda film with the testimonies of the four families demonstrate how the one-sided and State-sponsored discourse functioned to support and even instigate fear amongst the victims and their families for many years.

2. https://nasional.kompas.com/read/2019/11/23/17112481/menhan-prabowo-mintapemberontakan-pki-diajarkan-di-sekolah, accessed on 1 January 2020.

3. Robert Lemelson, Laurence J. Kirmayer, and Mark Barad, "Trauma in Context: Integrating Biological, Clinical, and Cultural Perspectives", In L. Kirmayer, R. Lemelson, \& M. Barad (Eds.), Understanding Trauma: Integrating Biological, Clinical, and Cultural Perspectives. Cambridge: Cambridge University Press, 2007. p. 451-474 ; Robert Lemelson, Ninik Supartini, and Emily Ng. Ethnographic Case Study: Anak PKI: A Longitudinal Case Study of the Effects of Social Ostracism, Political Violence, and Bullying on an Adolescent Javanese Boy. Cambridge : Cambridge University Press, 2010, p. 379-389. 


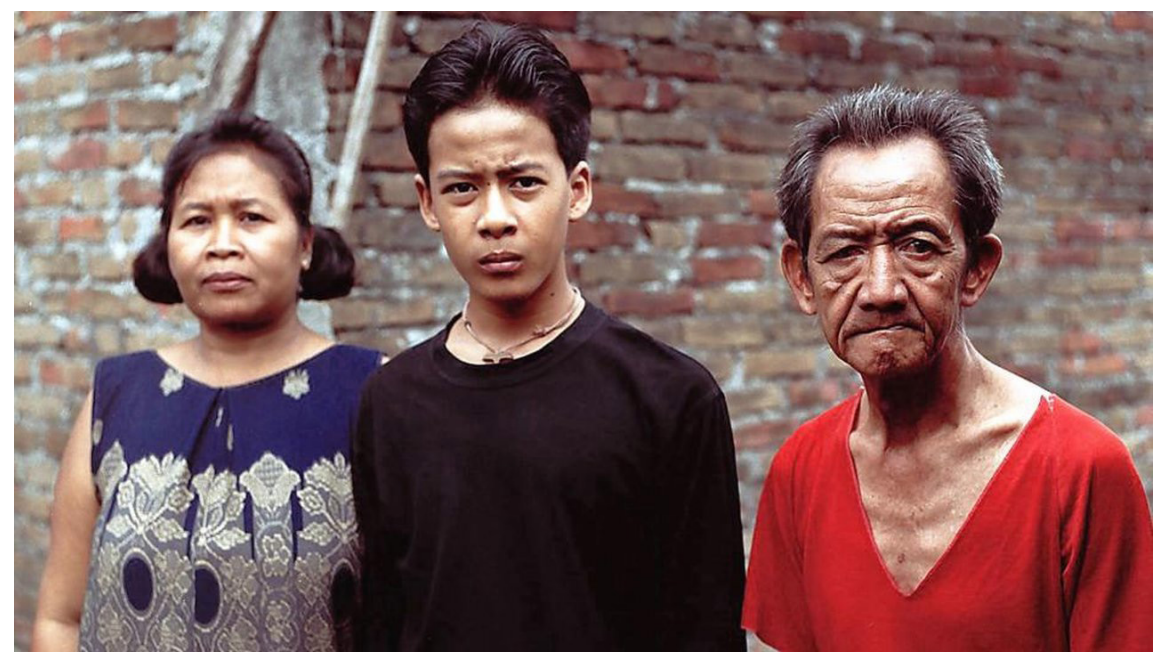

40 Years of Silence: An Indonesian Tragedy

\section{Degung and Kereta}

The first part of the film takes place in Bali, focusing on two men whose fathers were murdered during the 1965 genocide: Degung Santikarma and Kereta. Both tell their stories with a certain degree of doubt. For Degung, it was because he was too young and uninformed about what happened at that time. In the case of Kereta, his mental state renders him confused when narrating his story.

Degung says that his father was important and well-off. However, he never mentions what his father actually did. If he was important, what made him important? What was his position? Degung also says that his parents often went overseas, probably for conferences. Again, he is not sure what these conferences were about because he was too young then. Degung's father was arrested and later murdered in 1965. However, Degung also does not know how he was murdered. Degung's uncertain narrative is not the only one here. It is common for many of these victims and their families not to have clear ideas about what happened to their own families during the 1965-66 incidents. Pak Kereta is another example. He lives in a rural area of Bali. Kereta states that he witnessed the mass murder of many people and the brutal assassination of his own father in the family compound. Some of the perpetrators were his neighbours, and his own cousin also took part in the violence towards his father. His father's body was eventually buried in a local cemetery, but was never given the proper Balinese cremation ceremony. According to Balinese belief, not being given such a cremation will mean that the person's soul cannot rest. 
This could be the reason why Kereta has delusions and keeps seeing the ghosts of communist people calling him. But Kereta's delusions also raise the possibility that his story about his father and the other murdered communists are also delusory. Ironically, Kereta describes the ghosts of the communists as "evil" beings who entice him to join the Indonesian Communist Party, something that he resists. He wears camouflage clothes and a military helmet to keep these communist ghosts away. The film shows how Kereta goes around in this clothing, as he believes that the military symbols can appease and protect him against the dangerous black spirits of the communists. The paradox here is that Kereta, who suffers from the impact of the military brutality, seeks refuge by adopting the perpetrator's image.

\section{Budi and Lanny}

Besides Degung and Kereta in Bali, the film presents the stories of two families in Central Java, those of Budi and Lanny. Budi lives in an orphanage in Yogyakarta, although his parents are still alive. From this film, we learn that Budi's parents decided to move him there because Budi had been violently bullied by the children around him. Budi's father, Mudakir, was accused of being a communist because he fell in love with the same girl as the son of the head of his village. After his release, Mudakir married Sumini, whose father had also been imprisoned as an alleged communist. In their marriage, Mudakir abused Sumini. The victim becomes the perpetrator : he beat up Sumini until her mouth bled and at one point, he nearly killed her. While Kereta adopts the perpetrator's image, Mudakir adopts the perpetrator's behaviour.

Both of the sons of Mudakir and Sumini have a tendency towards disruptive behaviour. When Budi first entered the orphanage, he had a bad temper, was often restless and out of breath. His elder brother, Kris, also expresses a lack of confidence in his future. Smoking while aimlessly wandering with other street kids, Kris admits that he has often been scolded as "a child of communists" and has been blamed if anything bad happened in his village. For many people, Budi and Kris may be seen merely as trouble-makers or good-for-nothings, but the film makes us ponder and understand that there is a long past behind their present troubles.

The fourth family that this film focuses on is that of Lanny. She was born into a very well-off and respected family. One day in 1965, hundreds of people threw stones and axes at their house, while shouting her father's name. Lanny's mother told how their house was looted then and as a result, they became very poor. But she asked her children to be tough and to work hard. Interestingly, Lanny's mother never mentions communism but keeps insisting that her family's identity is Chinese: "Show them that you are really Chinese, not just fake Chinese." She opposes the stigma and sufferings in their lives by insisting that as Chinese, the family can persevere and survive, as though by adopting this identity, they can oppose the injustice. 


\section{The Central Condition of the Society}

By combining these four families, the film demonstrates the underlying cause of these disjointed narratives. Having an interest in mental illness and psychological issues in Indonesia, Robert Lemelson notes that in both Java and Bali, people adopt convictions that may contribute to the recovery process. ${ }^{4}$ In the case of Kereta, his delusion of seeing ghosts can be viewed as a spiritual experience by the local people. And Kereta aligns his delusion with people's conviction around him, that communists are evil. In the same way, he tries to tackle his delusion with another ideologically accepted convention: the wearing of military attire.

In Java, Lemelson notes that the ngemong approach", "used for children or for someone who appears to be 'acting like a child', encompasses tolerance of aggressive and impulsive behavior" and ensures "an absence of criticism, blame, or hostility" towards such behaviour. ${ }^{6}$ This kind of approach does not only apply in Java, but is adopted widely in Indonesia. Most Indonesians are familiar with the proverb "Sing waras ngalah" (The sane/healthy one has to give in), implying that aggressive and anti-social behaviour should be considered as coming from insane or sick people and therefore treated as such.

Nevertheless, in this film, most of the victims have to adopt the role of ngemong in conformity with the society surrounding them. Degung for instance, analyses the brutality of the people around him as part of the propaganda of the government. He even approaches one of the perpetrators who lives next door to his family's home, and talks about the death of his father. Degung mentions the suspicions that the victims had about this neighbour: that he was one of the decision makers in the 1965 mass-murder in the village. His neighbour, while being friendly, still sounds rather threatening by claiming that if he was truly "that kind of person, I would have finished you all off." Somehow, with a threatening tone, he implies that Degung has either to be grateful to him or stop suspecting him. Degung's face registers a bit of a shock, but he remains calm and polite. Here, he acts as the person who understands, the person who does the ngemong.

In relation to the treatment of the neighbours to Budi's family, it is Budi's mother that shows the attitude of ngemong. She has to tolerate her husband's

4. 40 Years of Silence: an Indonesian Tragedy. Film Guide. www.der.org, accessed on 22 December 2019.

5. Ngemong is Javanese for 'empathy'.

6. Several scholars such as Douglas Kammen, John Roosa, Robert Cribb and Saskia Wieringa have emphasized the role of the Indonesian army in this genocide. Brad Simpson and Jeffrey Robinson have pointed to the involvement of several Western countries including the United States, the United Kingdom and Australia in assisting the operations behind the 1965 genocide. Recent findings by Jess Melvin in Aceh demonstrate that this genocide was planned, and that Soeharto's role in these incidents was crucial. 
abuse as well as the society's contempt stating: "Maybe I was immune to slander and pain." While she is victimised in multiple ways, she is the one who is forced to show tolerance and the absence of anger and criticism against the attackers and abusers. It is only after her children are victimised that she feels her sadness and pain.

Lanny in the end finds consolation in Buddhism and makes peace with her anger. She even organizes relief for the village where her father had been murdered, after a massive earthquake. She takes on the role of ngemong, of trying to understand her society and the injustice that has been inflicted on her family. While watching the film, one has the impression that the movie aims at conveying a message: the sufferers of the mental disorder inflicted during the 1965 incidents are not only the main characters portrayed, but also the societies surrounding the victims as they show aggressive, malicious and erratic behaviour. The "truth and nothing but the truth" narrative repeated by different Indonesian governments has justified the "insanity" of the people and normalised the mental illness of the society. Importantly, the claim of a single truth prevents the possibility of other discourse(s) - such as the ones portrayed in this film - come to light and reduces the possibility of Indonesia undertaking enlightening debates about its history.

\section{Reference}

Anderson, Benedict. "How Did the General Die.” Indonesia 43, April 1987.

Cribb, Robert, ed. The Indonesian Killings of 1965-1966: Studies from Java and Bali. Clayton: Centre for Southeast Asian Studies, Monash University Australia, 1990.

Kammen, Douglas and Katharine McGregor (eds.). The Contours of Mass Violence in Indonesia, 1965-1968. Honolulu : University of Hawai'i Press, 2012.

Lemelson, Robert and Annie Tucker. Afflictions: Steps Toward a Visual Psychological Anthropology. London: Palgrave Macmillan, 2017.

Lemelson, Robert, Laurence J. Kirmayer, and Mark Barad. "Trauma in Context: Integrating Biological, Clinical, and Cultural Perspectives.” In L. Kirmayer, R. Lemelson, \& M. Barad (Eds.), Understanding Trauma: Integrating Biological, Clinical, and Cultural Perspectives. Cambridge: Cambridge University Press, 2007, p. 451-474.

Lemelson, Robert, Ninik Supartini, and Emily Ng. Ethnographic Case Study: Anak PKI: A Longitudinal Case Study of the Effects of Social Ostracism, Political Violence, and Bullying on an Adolescent Javanese Boy. Cambridge : Cambridge University Press, 2010.

Robinson, Geoffrey B., The Killing Season: A History of the Indonesian Massacres, 1965-66, Princeton : Princeton University Press, 2018.

Roosa, John. Pretext for Mass Murder: The September 30 Movement and Suharto's Coup d'Etat in Indonesia. New Perspectives in SE Asian Studies. Madison : University of Wisconsin Press, 2006.

Simpson, Bradley, Economists with Guns: Authoritarian Development and US-Indonesian Relations, 1960-1968, Stanford: Stanford University Press, 2008.

Wieringa, Saskia and Nursyahbani Katjasungkana, Propaganda and the Genocide in Indonesia: Imagined Evil, London and New York: Routledge, 2018. 